\title{
Benedetto Varchi on the Soul: Vernacular Aristotelianism between Reason and Faith
}

\author{
Marco Sgarbi
}

\section{INTRODUCTION}

Benedetto Varchi (1503-65) was one of the most important and complex figures in the Italian intellectual landscape of the sixteenth century. His interests ranged from history to literary criticism, from science to poetry; yet, until recently, his reputation has been based solely upon his interpretation of Dante and Petrarch, his discussion of the "question of the language," and his activity generally as a man of letters and pedagogue at the Accademia Fiorentina. ${ }^{1}$ Very few studies have sought to reconstruct Varchi's profile as a philosopher, and most that do-by Bruno Nardi, Eugenio Garin, Cesare Vasoli, and others-have focused on his alleged Averroism. ${ }^{2}$

\footnotetext{
${ }^{1}$ For an overall account of Varchi's life, work, and historical context, see Umberto Pirotti, Benedetto Varchi e la cultura del suo tempo (Florence: Olschki, 1971); and Annalisa Andreoni, La via della dottrina. Le lezioni accademiche di Benedetto Varchi (Pisa: ETS, 2012).

${ }^{2}$ Cf. Bruno Nardi, Studi su Pietro Pomponazzi (Florence: Le Monnier, 1965), 322-29, 380-82; Giovanni Papuli, "Benedetto Varchi: logica e poetica," in Studi in onore di Antonio Corsano (Manduria: Lacaita, 1970), 527-72; Eugenio Garin, "Benedetto Varchi e la teoria dell'eterno ritorno," in Umanesimo e Rinascimento. Studi offerti in onore di Paul Oskar Kristeller (Florence: Olschki, 1980), 155-72; Paolo Cherchi, "Due lezioni di Benedetto Varchi ispirate da J. L. Vives," Lettere Italiane 40 (1988): 387-99; Selene Ballerini, "Benedetto Varchi aristotelico ficiniano," Misure critiche 21 (1991): 25-42; Cesare Vasoli, "Benedetto Varchi e i filosof,," Benedetto Varchi 1503-1565, ed. Vanni Bramanti (Rome: Edizioni di Storia e Letteratura, 2007), 403-34.
}

Copyright $\odot$ by Journal of the History of Ideas, Volume 76, Number 1 (January 2015) 
Furthermore, such studies are based for the greater part on the philosophical fragments published in the nineteenth-century editions of Varchi's works, the reliability of which has been questioned by the latest philological investigations. ${ }^{3}$ None of them consider the mountain of unedited manuscript material which is to be found in the Filze Rinuccini of the Biblioteca Nazionale Centrale (hereafter BNC) in Florence. This oversight has led to a misleading image of Varchi as an amateur philosopher. Yet much of Varchi's life was spent poring over philosophical texts, in particular those of logic, ethics, and natural philosophy, and discussing complex philosophical problems such as the immortality of the soul, animal generation, and the structure of the universe. The secrets of philosophy were revealed to Varchi at an early age in the school of the Neoplatonist Francesco Verino the Elder (1474-1541). His knowledge of Aristotelian psychology was then fostered by the philosophical debates at the University of Padua and at the Accademia degli Infiammati. He then moved to Bologna where he followed the lectures of his beloved teacher Ludovico Boccadiferro (1482-1545), before becoming in 1543 one of the leading figures of the Accademia Fiorentina under the patronage of Duke Cosimo I.

A reassessment of Varchi's impact must rest upon a solid understanding of his thought within a context of intellectuals that included the likes of Cardinal Gasparo Contarini (1483-1542), Sperone Speroni (1500-1588) and Ludovico Beccadelli (1501-72), whose purpose, in the age of the Counter-Reformation, was to popularize Aristotle's doctrines and reconcile them with Christian religion. Above all, this new appraisal is possible only by means of a full-fledged investigation of Varchi's manuscript writings on psychology, which I shall begin here. Varchi's manuscripts reveal the depth of his familiarity with philosophy and his originality as a thinker, especially with regard to his personal reinterpretation of the ancient Greek commentators of Aristotle. In particular, I wish to show that Varchi was not an Averroist, as is often claimed on the basis of his Dante lectures, if by Averroism one means, to cite a recent formulation, "the attribution to Aristotle of Averroes's doctrine of the unity of the agent and possible intellects for all men and therefore the denial of the immortality of the individual human soul." 4 This is particularly important in contexts such as Padua and Bologna, Italy's two main centers of scholarly philosophical study where Varchi

${ }^{3}$ Cf. Annalisa Andreoni, “Questioni e indagini per l'edizione delle 'Lezioni accademiche,'” Benedetto Varchi 1503-1565, ed. Vanni Bramanti (Rome: Edizioni di Storia e Letteratura, 2007), 1-24.

${ }^{4}$ John Monfasani, "The Averroism of John Argyropoulos and His 'Quaestio utrum intellectus humanus sit perpetuus,'” I Tatti Studies in the Italian Renaissance 5 (1993): 165. 


\section{Sgarbi $\downarrow$ Benedetto Varchi}

spent a number of his formative years. In both places it seemed to many that no one could be truly Aristotelian or even a philosopher if he did not first embrace Averroes's doctrines. ${ }^{5}$

In these manuscript writings, Varchi rejects Averroistic doctrines and seeks to reconcile Aristotelian psychology with the truth of religion. In so doing, Varchi appropriates the interpretation of Aristotle offered by Themistius (fourth century $\mathrm{CE}$ ) through the filter of the writings of Marcantonio Zimara (ca. 1460-1532), an exegesis that allows him to defend the immortality of the human soul while safeguarding the doctrines of Christian faith. Zimara, along with Pietro Pomponazzi (1462-1525), was one of the foremost Aristotelians of the time owing to his comprehensive knowledge of Aristotle and Averroes. As he himself admits, Varchi's treatment of psychology is based on Zimara's Theoremata seu memorabilium propositionum limitationes (1523) and Tabula dilucidationum in dictis Aristotelis et Averrois (1539). ${ }^{6}$ I will argue that Varchi became acquainted with Aristotelian psychological doctrines prior to his arrival in Bologna, so his time there would thus appear to be less decisive than was previously thought for his philosophical development. This manuscript material should be examined together with Varchi's lectures on Dante, which are a genuine companion to Aristotelian psychology rather than an exercise in literary criticism, as one might be led to believe.

What makes Varchi's psychological writings so remarkable is that they are a part of his project to vernacularize the entire corpus of Aristotelian philosophy, which included, as he reveals to his friend Piero Vettori, his unfinished translations of Aristotle's logical and ethical corpora. ${ }^{7}$ Modern surveys of the question of the immortality of the soul in the Renaissance give scarce, if any, attention to works in the vernacular, since initially the problem was discussed mainly in Latin among university professors and men of religion. Yet parallel to the Latin debate there was a conspicuous number of vernacular works which deserve attention for their various approaches to this momentous problem. ${ }^{8}$ Some sought to reconcile rational

\footnotetext{
${ }^{5}$ This was the opinion of Gasparo Contarini, a key figure at the time, cf. Giovanni Di Napoli, L'immortalità dell'anima nel Rinascimento (Turin: Società Editrice Internazionale, 1963), 278.

${ }^{6}$ Benedetto Varchi, Opere (=O) (Trieste: Lloyd Austriaco, 1859), 2: 657. On Zimara's psychological doctrines cf. Alba Paladini, Il pensiero psicologico e gnoseologico di Marco Antonio Zimara (Lecce: Congedo, 2001), 114-56.

${ }^{7}$ Cf. British Library, Add. Ms. 10273, cc. 223r-4r. On vernacular Aristotelianism, cf. David A. Lines, "Rethinking Renaissance Aristotelianism: Bernardo Segni's Ethica, the Florentine Academy, and the Vernacular in Sixteenth-Century Italy," Renaissance Quarterly 3 (2013): 824-65.

${ }^{8}$ So far, I have compiled a list of 16 original works, both in manuscript and printed form.
} 
arguments with the truths of faith, while others dealt with the problem of immortality only according to rational arguments in contrast to religion; others still argued solely in favor of theological positions. Many originally aimed to reconcile Platonism and Aristotelianism with reference to ancient Greek commentators, while most connected problems of speculative philosophy, such as the existence of separate intelligences, with moral issues like happiness and virtue. These vernacular writings were not merely vehicles for popularizing a debate carried on elsewhere in Latin, but were in their own right serious contributions to the debates.

Varchi's vernacular treatises provide precious insights into his own philosophical thought; yet they also open up an important chapter in this hitherto neglected area of Renaissance studies. They provide a more nuanced understanding of the problem of the immortality of the soul, and also of the social locations of its discussion. These vernacular texts move the issue beyond the Latin circles of the universities and religious orders into the courts and academies, such as the Accademia degli Infiammati in Padua and the Accademia Fiorentina. A particularly striking aspect of Varchi's attempt to translate and popularize knowledge is that he did not limit himself to passively receiving and transmitting Aristotelian philosophy, as did many other Aristotelians of the time, in particular those who wrote in the vernacular. Rather, he was actively engaged in reformulating ideas with a view to adapting philosophical material to his intended audience, which consisted mainly of men of letters, academics, and women. ${ }^{9}$ This approach did not necessarily involve a simplification of knowledge, but it did involve widespread dissemination throughout all cultural levels of society. ${ }^{10}$

Varchi's psychological writings are now kept in BNC Rinuccini folder II.VIII.136, which contains a variety of treatises in the vernacular language. ${ }^{11}$ Since they are not autograph manuscripts, it is not always easy to determine their exact nature; about their authorship, however, there is no question, since Varchi refers to treatises contained in this folder in some of his letters. ${ }^{12}$ They may be preparatory notes for his lectures, or abstracts

\footnotetext{
${ }^{9}$ Cf. Luca Bianchi, "Volgarizzare Aristotele: per chi?," Freiburger Zeitschrift für Philosophie und Theologie 59 (2012): 480-95.

${ }^{10}$ Cf. O, 2: 490.

11 (1) Divisione dell'anima (27r-33v), which contains (a) Dell'anima vegetativa (29r29v); (b) Dell'anima sensitiva (29v-30v); (c) Dell'anima intellettiva (30v-33v); (2) Delle sensazioni (35v-42r), which contains (a) Del senso (36v-37v); (b) Della sensazione ( $37 \mathrm{v}-$ 38r); (c) Del sensorio (38r-38v); (d) Del sensibile (38v-41r); (e) Del mezzo (41r-42r); (3) De sensi interiori $(43 \mathrm{r}-46 \mathrm{r})$, which contains (a) Del senso comune $(43 \mathrm{v}-44 \mathrm{r})$; (b) Della fantasia (44v-45r); (c) Della cogitativa (45r-45v); (d) Memoria (45v-46r); (e) Del luogo ovvero de i sensi interiori (46r-47r); (4) Dell'intellezione (48r-51v).

${ }^{12}$ Cf. Andreoni, “Questioni e indagini per l'edizione delle 'Lezioni accademiche,"” 16.
} 


\section{Sgarbi $\uparrow$ Benedetto Varchi}

from them, or even, as seems more plausible, a companion to Aristotelian philosophy transcribed by one of his followers, Lelio Bonsi. ${ }^{13}$ Despite being distinct works, however, they show a continuity that suggests that Varchi did indeed intend to compose an overall work on those issues, which were traditionally related to the exposition of Aristotle's De anima, and to which collectively they constitute a reasonably comprehensive commentary.

\section{CONTEXT}

In order to understand Varchi's psychological conceptions and his attitude towards these philosophical problems, we must turn first to debates surrounding the soul in the Renaissance, a topic that has received wide coverage in the recent past. ${ }^{14}$ By the end of the fifteenth century, we find at least four different schools of thought. The first, held by authors such as Thomas Aquinas (1225-74), supports the idea of the personal immortality of the soul and its philosophical demonstrability. The second, maintained by Averroes, argues that there are two separate intellects, the possible and the agent, both immortal and unique to all human beings. The third position, upheld by Marsilio Ficino (1433-99) and the Renaissance Platonists, maintains that the human soul has a separate life and independent destiny from the body, since every human being is endowed with a natural appetite that induces it to return to its divine origins, to the celestial homeland. The fourth and most recent position, following the rediscovery of the ancient Greek commentators of Aristotle, follow Alexander of Aphrodisias (third century $\mathrm{CE}$ ), who supports the view that the human soul is mortal and that only the agent intellect, identified with God, is immortal.

In the last quarter of the fifteenth century, these four positions were the

${ }^{13}$ The handwriting is the same as that of the manuscript Accademia dei Lincei, Corsini 1352 (44 G 8-9) containing Varchi's Storie fiorentine, transcribed by Bonsi, cf. Anna Siekiera, "Benedetto Varchi," in Autografi dei letterati italiani. Il Cinquecento (Rome: Salerno, 2009), 343. I thank Dario Brancato for his suggestion.

${ }^{14}$ Cf. Étienne Gilson, “Autour de Pomponazzi. Problématique de l'immortalité de l'âme en Italie au début du XVI siècle," Archives d'histoire doctrinale et littéraire du Moyen Âge 26 (1961): 163-279; Eckhard Kessler, "The Intellective Soul," The Cambridge History of Renaissance Philosophy, ed. Charles B. Schmitt, Quentin Skinner, and Eckhard Kessler (Cambridge: Cambridge University Press, 1988), 485-534; Paul R. Blum, “The Immortality of the Soul," in The Cambridge Companion to Renaissance Philosophy, ed. James Hankins (Cambridge: Cambridge University Press, 2007), 211-33; Eckhard Kessler, Alexander of Aphrodisias and his Doctrine of the Soul: 1400 Years of Lasting Significance (Leiden: Brill, 2011). 
subject of heated debate, especially at the Universities of Padua and Bologna. The Parisian Condemnation of Étienne Tempier (d. 1279) in 1277 did not deter Averroistic readings of Aristotle, ${ }^{15}$ which on the contrary, especially in Padua, became extremely popular through the writings of authors such as Nicoletto Vernia (1420-99) and Agostino Nifo (c. 1469-1538). ${ }^{16}$ In reaction to the propagation of Averroistic doctrines, on May 4, 1489, the Bishop of Padua, Pietro Barozzi (1441-1507), issued an edict against debating the problem of the unity of the intellect in public (publice disputare), namely in churches and public squares during solemn events in the presence of authorities and large audiences. The edict, however, did not affect lectures in the classrooms of the universities, with the result that Averroistic doctrines continued to be taught and disseminated. ${ }^{17}$

A more general condemnation came during the Fifth Lateran Council on December 19, 1513, with Leo X's bull Apostolici regiminis sollicitudo. The historical genesis of the bull is controversial, but recent scholarship suggests that in all probability a significant factor was Renaissance Platonism-a current of thought that influenced Varchi's position too. ${ }^{18}$ In general, the bull has been variously viewed as a condemnation of the Averroist and Alexandrist doctrine of the soul, a declaration of the individual immortality of the human soul, or a condemnation of the so-called doctrine of the double truth. ${ }^{19}$ Not all the members of the commission of the Apostolici regiminis were in agreement with the bull's prescriptions, however: Cardinal Cajetan (1469-1534), for example, disapproved of "the second part of the bull, which commands philosophers to teach, and publicly to persuade of, the truth of faith." ${ }^{20}$ In his various works, Cajetan argued that

${ }^{15}$ Cf. Luca Bianchi, Il vescovo e i filosofi: La condanna parigina del 1277 e l'evoluzione dell'aristotelismo scolastico (Bergamo: Lubrina, 1990); Luca Bianchi, “1277: A Turning Point in Medieval Philosophy?,” Was ist Philosophie im Mittelalter?, ed. Jan A. Aertsen and Andreas Speer (Berlin and New York: Walter De Gruyter, 1998), 90-110.

${ }^{16}$ Cf. Edward P. Mahoney, Two Aristotelians of the Italian Renaissance: Nicoletto Vernia and Agostino Nifo (Aldershot: Ashgate, 2000).

${ }_{17}$ Cf. Bruno Nardi, Saggi sull'aristotelismo padovano dal secolo XIV al XVI (Florence: Sansoni, 1958), 155-56.

${ }^{18}$ Cf. Paul O. Kristeller, "The Theory of Immortality in Marsilio Ficino," Journal of the History of Ideas 1 (1940): 299-319; John Monfasani, "Aristotelians, Platonists and the Missing Ockhamists: Philosophical Liberty in Pre-Reformation Italy,” Renaissance Quarterly 46 (1993): 247-78.

${ }^{19}$ Cf. Di Napoli, L'immortalità dell'anima nel Rinascimento; Eric A. Constant, "A Reinterpretation of the Fifth Lateran Council Decree 'Apostolici regiminis' (1513)," Sixteenth Century Journal 33 (2002): 353-76; Luca Bianchi, Pour une histoire de la "double vérité", (Paris: Vrin, 2008).

${ }^{20}$ Cf. Gian Domenico Mansi, Sacrorum conciliorum nova et amplissima collectio (Venice: Zotta, 1773), 843. 
the immortality of the soul found no support in Aristotle's thesis, ${ }^{21}$ and that immortality was not really demonstrated by philosophers; nor did it seem demonstrable with philosophical arguments in any case, faith alone being capable of giving us such a certainty. ${ }^{22}$

Pietro Pomponazzi, in his controversial De immortalitate animae (1516), established the impossibility of demonstrating the immortality of the soul with philosophical arguments, while maintaining that the Christian doctrine of the immortality of the soul could only be accepted on faith. In his view, revelation offers a kind of certainty of the immortality of the soul that is not attainable by reason. Even philosophers who have demonstrated the soul's mortality rationally can believe in its immortality as a religious truth. These two separate levels, philosophy and faith, co-exist in Pomponazzi without contradiction, because each has its own field of inquiry. For Pomponazzi, the religious belief in the immortality of soul in no way entails the abandonment of reason, and nowhere does he assert the superiority of the truth of reason over the truth of faith; rather he treats them as two distinct standpoints concerning different matters. ${ }^{23}$ His arguments were highly controversial, however, and were harshly criticized by both philosophers and men of religion. The controversy was to occupy philosophical debate for over half a century, and was very present in Varchi's mind. ${ }^{24}$ This complex and variegated scenario, with its acrimonious dialogue between philosophy and religion, provides the setting in which we must understand Varchi's psychological ideas and his attempt to reconcile rational arguments with the truths of faith.

\section{THE DIVISION OF THE SOUL AND THE CONTAINMENT THESIS}

The first manuscript treatise, entitled Divisione dell'anima, offers a general introduction to Aristotelian psychology. Varchi begins by identifying man's position in the cosmos in relation to all other living beings. He claims that

${ }^{21}$ Cf. Thomas De Vio, Commentaria De anima Aristotelis (Rome: Angelicum, 1938), 57-58.

22 Cf. Thomas De Vio, Parabolae Salomonis (Rome: Blado, 1542), 117-18. Cf. Antonio Petagine, "Aristotelismo e immortalità dell'anima. La proposta di Tommaso d'Aquino," Lo Sguardo 5 (2011): 1-19.

${ }^{23}$ Cf. Vittoria Perrone Compagni, "Introduzione," in Pietro Pomponazzi, Trattato sull'immortalità dell'anima (Florence: Olschki, 1999), XCIII.

${ }^{24}$ Cf. Martin Pine, Pietro Pomponazzi: Radical Philosopher of the Renaissance (Padua: Antenore, 1986), 124-234. 
the species of living beings are like numbers: they are infinite, different from each other, and of varying degrees of perfection. The diversity of living beings results from the fact that even if nature always tries to do its best, sometimes it is prevented from doing so by accident and fails to attain its original goal. ${ }^{25}$ Perfection is possible only when from brute matter the noblest thing that can be drawn from it is obtained. Among the material things, no doubt the noblest "down from the heaven of the Moon" is the human being. Its nobility and perfection are determined by its form, namely its intellect, or rational soul, "which encloses and contains in itself all the other souls." 26

This concept of containment of a soul in the others is fundamental to understanding Varchi's psychology, because the rational soul becomes the final form of all other souls, or rather of all the other parts or faculties of the soul. In another passage, Varchi writes that the vegetative soul is contained in the sensitive soul, in the same way as the triangle is contained in the square. ${ }^{27}$ This analogy derives from Aristotle's De anima $2.3414 \mathrm{~b}$ $31-32$, where it is established that "living beings constitute a series, each successive term of which potentially contains its predecessor, for instance the square the triangle, sensory power, the self-nutritive power." This conception of "containment," which played a central role in Themistius's Paraphrasis to Aristotle's De anima, at least two different editions of which Varchi had in his library, ${ }^{28}$ is particularly well developed, and owes its popularity to Zimara's Tabula. ${ }^{29}$ At the heart of Themistius's interpretation of the soul, there is on the one hand the identification of the Aristotelian concept of "form" and the Platonic notion of "idea," on the other the conception that matter is an indeterminate receptacle, which must be formed by God so that it can exist and be known. The process of determining and forming matter by means of the form is manifold. At the beginning there are the four primitive elements that constitute the basic structures of inanimate bodies, which are in potency organic bodies characterized by a vegetative

\footnotetext{
${ }^{25}$ Cf. Biblioteca Nazionale Centrale di Firenze, II.VIII.136 (=V), 27r.

${ }^{26} \mathrm{~V}, 27 \mathrm{v}$.

${ }^{27} \mathrm{~V}, 28 \mathrm{v}$.

${ }^{28}$ Cf. Biblioteca Nazionale Centrale di Firenze, II.VIII.142, 56v. It is possible to identify these two books as the Libri paraphraseos Themistii Peripatetici acutissimi, published by Ermolao Barbaro for the first time in 1499, and the same work edited by Barbaro but with the Contradictiones ac solutiones Marci Antonii Zimarae in dictis lucidissimi Themistii, published by Scoto in 1542 .

${ }^{29}$ Cf. Marcoantonio Zimara, Tabula dilucidationum in dictis Aristotelis et Averrois (Venice: Scoto, 1537), 17v: "Non per aliam formam homo est vivens, et per aliam est animal, vegetativum enim est in sensitivo, sicut trigonum in tetragono. ..."
} 


\section{Sgarbi $\downarrow$ Benedetto Varchi}

soul. The vegetative soul is the actuality of inorganic bodies, but it is in potency the sensitive soul. The sensitive soul is the form and the actuality of the vegetative soul. In the most perfect animals, imagination is the form of the sensitive soul, and it is in potency the possible intellect. Possible intellect is in potency the agent intellect, which is conversely the form and the actuality of the former. From prime matter to agent intellect there is a chain of forms, each of which is the perfection and the actuality of what precedes and the potency and subject of what follows. ${ }^{30}$ Varchi follows Themistius in maintaining that before dealing with the rational soul it is necessary to consider "not only how many are the souls, but also the levels of life, and all their powers." 31 Thus it is possible to reconstruct the whole chain of the forms of the soul and their various relations.

In general, the "souls" are three: "the first one and the less perfect of them is called vegetative, the second sensitive, the third and last intellectual." 32 Varchi points out that, according to the theologians, all three souls are one single soul; they are in fact the same soul, one contained in the others. In the unity of the soul-Varchi states—“we, Christians, must believe," as do many other pagan philosophers. ${ }^{33}$ This means that the soul is always one single entity, but it is virtually and logically separated in its functions and operations. Varchi is clearly referring to Aristotle's De anima 2.2413 b 2, where the Stagirite establishes only a rational or logical distinction among these souls ( $\tau \hat{\omega} \delta \dot{\varepsilon} \lambda \hat{\text { ó }} \gamma \omega$ ö $\tau \iota ~ \varepsilon ̈ \tau \varepsilon \varrho \alpha)$, supporting its indivisibility as a form of the body. This first reference to theologians is quite significant because it shows Varchi's concern with following Christian doctrine, even though he adds that it is a truth not only of faith, but also of reason, since a number of philosophers, including some pagans, agree with this idea. Furthermore, Varchi makes it clear from the outset that he is not endorsing the Averroistic standpoint, which maintained that the possible and agent intellects were two substances separate from each other and from the body; that is, from the vegetative and sensitive souls. For this reason, for the sake of the indivisibility of the soul, Varchi also attacks the most naïve of Platonic positions, according to which souls are not distinguished only by operations, but also by the place where they are located and operate: the vegetative soul, which Plato calls also concupiscible, was located in the liver; the sensitive soul, also called irascible, in the heart; the rational soul

\footnotetext{
${ }^{30}$ Cf. Themistius, Themistii in libros Aristotelis de anima paraphrasis (Berlin: Heinze, 1899), 98-105.

${ }^{31} \mathrm{~V}, 27 \mathrm{v}-28 \mathrm{r}$.

${ }^{32} \mathrm{~V}, 28 \mathrm{r}$.

33 Ibid.
} 
in the brain. The greatest error of the Platonists and Averroists, according to the theologians, was the breaking up the unity of the soul, which on the contrary had to be defended, and the impossibility of explaining the reciprocal relationships among the various parts of the soul.

But while Varchi rejects the Platonic and Averroistic doctrines of the soul, he offers from the very beginning of his treatise a particular interpretation of the Aristotelian doctrine of the soul. He maintains, in line with the "Peripatetic sect," but in apparent contradiction with what he had stated previously about the unity of the human soul, that in the human being there are two distinct souls: "the sensitive soul, which is generable, and thus mortal, and the rational soul, which is ingenerated and thus immortal." 34 Varchi shares this opinion with his teacher Boccadiferro, whose lectures on the immortality of the soul (collected in Vatican Library, Vat. Lat. 4710) state that "in the human being there are two separate souls, the rational and the sensitive. Thus Themistius argues in 3 De anima, ch. 33, in his beautiful digression." 35 Themistius's position was particularly popularized by Zimara's Tabula. ${ }^{36}$ In this case, Varchi is following Themistius's interpretation, though not necessarily via Boccadiferro, as had been suggested by Bruno Nardi and Umberto Pirotti. ${ }^{37}$ For we can also find this doctrine of the separation of the two souls in Varchi's lecture Sur un sonetto del Bembo (1540) delivered at the Accademia degli Infiammati well before his stay in Bologna and his acquaintance with Boccadiferro. ${ }^{38}$ From the very beginning of his treatise, Varchi offers a particular interpretation of the Aristotelian doctrine of the soul in which he establishes a distinction between the sensitive and the rational soul. This is of the utmost importance if he is to save the immortal character of the human soul, but at the same time he supports the idea of the unity of the human soul according to faith

\footnotetext{
${ }^{34} \mathrm{~V}, 28 \mathrm{r}-28 \mathrm{v}$ : "Ma noi che seguitiamo la setta Peripatetica, diciamo che nell'huomo sono due anime distinte realmente. La sensitiva, la quale è generabile, e conseguentemente mortale; e la razionale, la quale è ingenerata, e conseguentemente immortale."

${ }^{35}$ Cf. Vat. Lat. 4710, ff. 251v-252r: “. . . . iuditio meo, omnium dictorum, qui est talis, quod in homine sint duae animae realiter seiunctae, scilicet rationalis et sensitive. Et iste modus est Themistii in 3 De anima, cap. 33, in illa pulcra digressione de hoc. ..."

${ }^{36}$ Cf. Zimara, Tabula dilucidationum in dictis Aristotelis et Averrois, 74r: "Intellectus enim duplex apud Aristotelem et Theophrastum est, unus patibilis, et corruptibilis, quem communem illi vocant, et corpore non abiunctum: alter autem totum id quod ex intellectu agente et intellectu potentiae componitur, quem et separatum à corpore et incorruptibilem, et ingenitum statuunt. Them. 3 de Anima cap. 39."

${ }^{37}$ Cf. Nardi, Studi su Pietro Pomponazzi, 322-36; Pirotti, Benedetto Varchi e la cultura del suo tempo, 67-73. On Varchi's knowledge of Aristotelian psychology during the Paduan period, cf. Andreoni, " 'Sangue perfetto che poi non si beve . . .': Le lezioni di Benedetto Varchi sul Canto XXV del Purgatorio,” Rinascimento 44 (2004): 162.

${ }^{38}$ Cf. O, 2: 562-63.
} 


\section{Sgarbi $\uparrow$ Benedetto Varchi}

and theological positions. How is it possible to reconcile these two apparently contradictory positions?

To solve this problem, Varchi starts by examining Aristotle's definition of the soul, which is "first actuality, that is the substantial form of a natural, organic body, that is non-homogeneous or composed by different parts, that is potentially alive." ${ }^{39}$ This definition, according to Varchi, "besides being very difficult to understand, it is not unambiguous which, as we have said, a true definition must be-but analogous," ${ }^{40}$ does not explain the various relations among the parts of the soul, and does not give an account of its unity and immortality. For this reason, in Varchi's view, it is better to consider Aristotle's second definition of the soul, conceived by its operations, as the "principle through which we live, sense, move and understand." ${ }^{41}$ It is according to these faculties that the soul must be investigated.

\section{SENSITIVE SOUL}

In general, as already noted, Varchi recognizes three main faculties of the soul: vegetative, sensitive, and rational. Varchi's treatment of the vegetative and sensitive soul, which is barely more than a summary of the main Aristotelian doctrines of the time, is not particularly original. ${ }^{42}$ The most innovative part is perhaps his reconstruction of the internal senses in the treatise Delle sensazioni. The internal senses are common sense, the imagination (or phantasy), the cogitative faculty (or discourse), and memory, their peculiarity being that they receive the sensible from the external senses, "but they can work [also] in absence of sensibles." 43 The most interesting internal senses are the imagination and the cogitative faculty. The imagination always works without sensibles, and can be of two kinds: either perfect, which works by means of memory and species to acquire knowledge, and is typical of perfect animals; or imperfect, which is nothing other than a confused sense typical of imperfect animals, and which we can find sometimes also in human beings. In the former case, the imagination is the faculty that divides and composes ideas; for Varchi, therefore, it seems capable

${ }^{39} \mathrm{~V}, 28 \mathrm{v}$. Cf. Aristotle, De anima 2.1412 a 27.

${ }^{40} \mathrm{~V}, 29 \mathrm{r}$.

${ }^{41}$ Ibid.

${ }^{42}$ On the analysis of the sensitive soul, see the Dichiarazione sopra la seconda parte del XXV Canto del Purgatorio, now in Andreoni, " 'Sangue perfetto che poi non si beve. ..,,", $182-223$.

${ }^{43} \mathrm{~V}, 30 \mathrm{r}$. Varchi's treatment of the internal senses is heavily based on Zimara's Tabula. Cf. Zimara, Tabula dilucidationum in dictis Aristotelis et Averrois, 139r-158v. 
of reasoning. It is noteworthy for Varchi that Aristotle in De anima 2 seemed to identify the imagination with passive intellect, a view the Florentine thinker supports in all his psychological treatises. ${ }^{44}$ Varchi writes:

This possible intellect can understand nothing that has not [previously] been in one of the five senses; this because it requires phantasms, that is species, and forms retained in the imagination and in the memory. This is what the Philosopher meant when he stated: and it is necessary that one understand and speculate phantasms; and because one cannot understand anything that is not universal; therefore, the understanding of singular and particular things is conjoined with sensation, that is the imagination or cogitative faculty. ${ }^{45}$

Varchi not only identifies the passive intellect with the imagination, but also the imagination with the cogitative faculty, or discourse. The cogitative faculty differs from the imagination only in that the latter abstracts solely from the presence of sensibles, while the former also from the accidents of sensibles, such as time and place, forming arguments and thoughts. In short, the cogitative faculty strips "individuals of all accidents"; ${ }^{46}$ it transforms particular and individual things into general and common things and serves them to the intellect. ${ }^{47}$ The imagination as cogitative faculty "is also called intellect, but passive, and always serves and administers [phantasms] to the intellect." 48

A closer look at Aristotle's text itself, however, reveals that the Stagirite never identified the imagination with the passive intellect in the way that Varchi understood it. This suggests that Varchi is in some way simplifying Themistius's interpretation of Aristotle. In De anima 1.4408 b 26-29, Aristotle questions whether "thinking, loving, and hating are affections not of the intellect, but of that which has intellect, so far as it has it." The answer is that when this subject decays, memory, hate, and love cease. Therefore, Aristotle writes, "they were activities not of mind, but of the

${ }^{44}$ Cf. V, 44v: "è ancora da notare che qu[e]sta virtù fu chiamata da Arist. nel 2. Dell'anima, intelletto passibile."

${ }^{45} \mathrm{~V}, 32 \mathrm{v}$.

${ }^{46} \mathrm{~V}, 45 \mathrm{v}$.

${ }^{47} \mathrm{~V}, 57 \mathrm{v}$.

${ }^{48} \mathrm{~V}, 32 \mathrm{v}$ : "La quale si chiama intelletto anch'ella, ma passivo, e sempre serve, e somministra all'intelletto." 


\section{Sgarbi $\downarrow$ Benedetto Varchi}

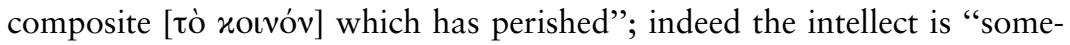

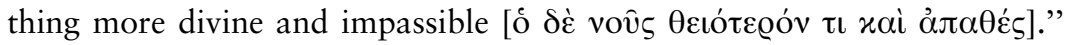
For unknown reasons, as Nardi has correctly noted, Themistius's interpretation of this passage is somewhat wrong, since he reads common intellect

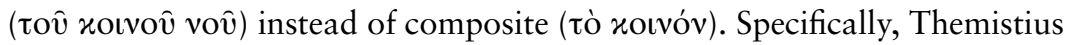

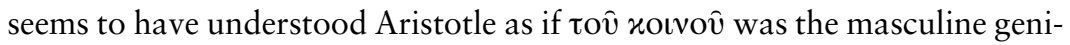
tive referable to vov̂s, rather than the neuter genitive tò xoเvóv, which refers to the composite. ${ }^{49}$ Themistius grounds his theory of common intellect on this misinterpretation. In his view it nothing other than the imagination, and he equates it with Aristotle's passive intellect (ó $\delta \dot{\varepsilon} \pi \alpha \theta \eta \tau$ ixòs vô̂s $\phi \theta \alpha \varrho \tau o ́ \varsigma)$. Varchi's main source on Themistius is probably Zimara's Tabula, in which he makes it clear that in the De anima 2 Aristotle deals with the cogitative faculty, and that the interpreters erroneously translate

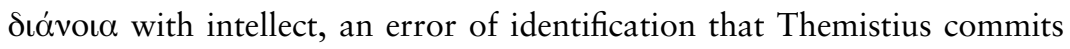
too. ${ }^{50}$

The possible intellect, Varchi asserts following Aristotle, is like a "white table in which nothing is written, but is apt to receive all forms of all things" from the imagination. ${ }^{51}$ For this reason, the possible intellect can be considered a passive faculty, because it consists in receiving the intelligibles, just as sensation is a passive faculty because it consists in receiving sensibles. The reception of these intelligibles is properly called "intellection." There are three elements that characterize intellection: (1) the faculty, that is the intellect; (2) the things to be understood, the intelligibles, in other words, which are nothing other than "the species retained in memory and called phantasms"; 52 (3) agent intellect, which abstracts from phantasms, transforming them from material and singular to immaterial and universal, allowing an understanding of universals in actuality, where before it was only in potency.

${ }^{49}$ Cf. Bruno Nardi, “Introduzione," in Tommaso D'Aquino, Trattato sull'unità dell'intelletto (Florence: Sansoni, 1947), 22; Bruno Nardi, Naturalismo e Alessandrismo nel Rinascimento (Brescia: Torre d'Ercole, 2012), 135.

${ }^{50}$ Cf. Zimara, Tabula dilucidationum in dictis Aristotelis et Averrois, 10v: "Aristotelis in 2 de Anima text. Com. 27. Ubi adverte quod textus graecus habet dianoticon, ubi communiter interpretes trastulerunt intellectivum, sed vere cogitativum dicitur: nam dianoea est in parte sensitiva ... unde animadverte quod inter potentias animae quae simul sunt in eadem essentia coniunctae, intellectus particularis qui dicitur passivus 2 de Anima coniungitur in homine cum aliis potentiis minus perfectis . . Inquit enim lucidissimus Themistius in commento super libro de Memoria et reminiscentia li. 2 cap. 14 Dianoea nihil aliud est quam cum imaginatione actio intellectus coniuncta.",

${ }^{51} \mathrm{~V}, 31 \mathrm{v}$.

${ }^{52} \mathrm{~V}, 48 \mathrm{r}$. 
Varchi points out that without the imagination, the intellect cannot receive material to understand, stressing that it is only by accident, through the imagination, that the intellect can understand particulars, because usually it apprehends only universals. In fact, while sensation receives merely singulars and accidents, such as colors, the intellect receives the essence, the substance and the universal.

Insofar as their objects are substances and universals, all intellects and rational souls of all human beings in their actuality are, for Varchi, in a certain sense, the same. If this were not the case, it would be impossible to explain the presence of common universal concepts in all human beings, or for that matter their capacity to understand and communicate with each other. In fact, when two people talk to each other on the same subject, either they understand one another or they do not; when they do understand the same thing, their act is the same and therefore in a certain sense the substance of the intellect is the same for the both of them. This happens only in the understanding, that is, when intelligibles are understood by the action of the agent intellect. This is an important conception that will lead Varchi to maintain a particular idea of the uniqueness of the agent intellect, but not, as we shall see, of the possible intellect.

What distinguishes the various singular intellects are the means and the tools without which they cannot understand and acquire knowledge, specifically external and internal senses..$^{53}$ There is always an individual disposition of each particular mind behind the acquisition of knowledge, and Varchi uses an interesting comparison to explain it:

no operations, whether material or spiritual, can be carried out if the agent and the possible intellects do not touch each other; whereby, as God works by means of heavens and heavens by means of light and movement, in the same way the human soul does what it does through a means and an instrument, that is by means of spirits. ${ }^{54}$

Spirits are generated according to Varchi from the thinnest part of the blood; thus he who has the best blood also has the best wit. Blood is produced in the liver and is perfected in the heart, hence the possibility of having a good wit. The weakness of the power of the soul depends on these spirits and nothing else. Despite their controversial and ambiguous nature,

${ }^{33}$ Cf. V, 50r-v.

${ }^{54} \mathrm{~V}, 51 \mathrm{r}-\mathrm{v}$. 


\section{Sgarbi $\downarrow$ Benedetto Varchi}

spirits for Varchi pertain to the sensitive soul and serve to prepare the possible intellect, which is, as we have seen, the imagination in actuality and the agent intellect in potency. Since the disposition of the spirits depends on sensation, the possible intellect, being the imagination in actuality, is naturally determined by them. The possible intellect relies upon this spiritual and sensible substratum, which is specific and proper to each individual. In this way, for Varchi, each particular being has its own specific intellect.

\section{RATIONAL SOUL}

At the beginning of his short treatise, Dell'anima intellettiva, Varchi states that the rational soul can be conceived of as divided "mainly into two parts; it is not that the soul, which is indivisible, has parts, but it is considered as having parts, namely powers, virtues, and faculties, because saying so we are more easily understood." 55 These two "parts" are specifically the possible intellect and the agent intellect, which in the human being constitute the very same rational soul; they are the same thing but, as we shall see, considered in different ways, one in potency and the other in actuality. On this particular occasion, Varchi emphasizes once again his alignment with the theological position establishing the indivisibility of the human soul, even if we can recognize many faculties within it.

The rest of the treatise is devoted to the examination of these two parts of the rational soul and their reciprocal relations. The possible intellect, Varchi points out, "is a pure and mere potency, which of itself has no nature, nor proper actuality." ${ }^{56}$ It therefore does not have a real nature, but is mere virtuality, and has as its own specificity the fact of being in between the imagination and the agent intellect. In potency, however, the receptivity of the possible intellect constitutes its perfection, because the more it knows things the more it becomes perfect, "so much that by learning them all it becomes one and the same thing with the agent intellect." Varchi adds that "in this conjoining of these two intellects, according to the greatest of Arabs, Averroes, the ultimate perfection and human happiness consist." 57 And again, in the Dichiarazione sopra que'versi di Dante nel diciassettesimo canto del Purgatorio (1564), Varchi states:

\footnotetext{
${ }^{55} \mathrm{~V}, 30 \mathrm{v}-31 \mathrm{r}$ : "L'anima razionale si divide primariamente in due parti; non che l'anima, la quale è indivisibile, habbia parti, ma si piglia parti, cioè potenze, virtù, e facoltà, e perche così dicendo siamo meglio intesi."

${ }^{56} \mathrm{~V}, 31 \mathrm{v}$ : "L'intelletto possibile non è altro che una pura, e semplice potenza, il quale da se non ha natura, ne atto nessuno proprio."

${ }^{57}$ Ibid.
} 
The greatest miracle of all miracles is that the human being through the habits of virtues and sciences can conjoin the possible intellect with the agent intellect, that is make them the same; and, consequently, that it [the human being] can understand without reasoning, and thus it is all things no longer in potency, but in actuality . . . in this conjoining consists, according to the insufficiently praised Arab, Avenr son of Rois, otherwise known as Alulide Rosaceo [Averroes], the last perfection, and consequently the highest happiness and human beatitude, since in it one sees, understands and enjoys intuitively and face-to-face the ultimate good. ... Only the human being, among all creatures terrestrial and celestial, has free will, and is capable of virtues and sciences through which it can ... conjoin the possible and the agent intellect and become almost like God. ${ }^{58}$

On the basis of these explicit statements, Nardi considered Varchi an Averroist, but this doctrine is not exclusively Averroistic; nor does a simple reference to Averroes necessarily determine his standpoint. This is particularly evident in the manuscript where Varchi refutes the positions of both Alexander of Aphrodisias and Averroes:

This possible or material intellect according to Alexander is mortal, but not for Averroes. It is true that he [Averroes] wants-and thus it seems necessary according to Aristotle-for the intellect not to be multiplied, that is that each individual has not his or her own intellect, but that it is only one for all human beings, which is contrary to theological truth, and one should not believe in it in any way. ${ }^{59}$

Varchi clearly rejects the Averroistic position of the uniqueness of the possible intellect in favor of theological truth, despite recognizing that by following Aristotle it is plausible that there might be only one possible intellect for all human beings. This means that for Varchi the possible intellect is proper to each individual human being. In this passage, Varchi is evidently

${ }^{58} \mathrm{O}, 2: 329$

${ }^{59} \mathrm{~V}, 31 \mathrm{v}-32 \mathrm{r}$ : "Questo intelletto possibile, ovvero materiale, secondo Alessandro è mortale, ma secondo Averrois no. Bene è vero, che egli vuole, e così par essere necessario, secondo Arist[otele], che egli non sia multiplicato, cioè che ciascuno individuo non habbia il suo, ma sia un solo in tutti gli huomini, la qual cosa è del tutto contraria alla verità teologica, ne si deve credere in verun modo." 


\section{Sgarbi $\uparrow$ Benedetto Varchi}

following the prescriptions of the Apostolici regiminis, seeking to bring all Aristotelian doctrines back to the Christian doctrine. In the Dichiarazione sopra la seconda parte del venticinquesimo canto del Purgatorio (1543), he states that

of the rational soul it is possible to speak in two ways: according to human reason and natural discourse, as the gentile philosophers did; and according to the supernatural light and divine inspiration, as our Christian theologians did. ${ }^{60}$

Varchi thus distinguishes two kinds of investigation on the rational soul, that of the philosophers and that of the theologians. In his view, these two positions are not necessarily in contrast to one another, although they do sometimes lead to divergent results. In case of divergence, truths of faith always take precedence over truths of reason, since one truth cannot contradict another, a point on which Varchi differs from Pomponazzi, who supported a sharp distinction between philosophy and religion. "In order not to occupy unworthily the professions of others," ${ }^{61}$ however, in this case that of the theologians, he chooses to consider only the philosophical positions. His purpose is thus "to follow in all respects Aristotle's doctrine and that of his commentators, especially, among the Greeks, the industrious Philoponus, among Arabs the very learned Averroes, and among the Latins the very truthful St. Thomas." ${ }_{62}$ Nonetheless, for Varchi, to follow the philosophical approach means to lead Aristotelianism back within the fold of religion. ${ }^{63}$

As was the norm in sixteenth-century Aristotelian commentaries, Varchi proceeded in his analysis by examining all theories presented by past philosophers, and in his view there were two main currents of thought on the soul. Some considered the soul as a body, or a corporeal thing, others as an immaterial thing. The opinions of those who claimed that the soul was corporeal were of little value, according to Varchi, and were all "very false, not only for the holy Christian law, but also for Aristotle." ${ }^{4}$ Once again, it was important for Varchi to assert that his position was perfectly compliant with the dictates of Christian doctrines, as well as aligned with the veracious ideas of Aristotle.

\footnotetext{
${ }^{60} \mathrm{O}, 2: 312$.

${ }^{61}$ Ibid.

${ }^{62}$ Ibid.

${ }^{63}$ Cf. O, 2: 666, 673.

${ }^{64}$ Ibid., 315.
} 
Against those who believed that the soul was corporeal there were two factions that upheld the view that the soul was incorporeal. Some philosophers maintained that the soul was separable from the body, and was therefore immortal, while others held that the human soul was inseparable from the body, and was thus mortal. Supporters of the latter thesis were Alexander of Aphrodisias and Galen, and more recently Pietro Pomponazzi, whom Varchi admired generally, ${ }^{65}$ but not for his psychological views, which he knew to be heretical. The thesis of the complete inseparability of the soul from the body, according to Varchi, was not the correct interpretation of Aristotle, who in truth "wants the soul to be substance, not accident; incorporeal, not corporeal; separable and immortal, not inseparable and mortal." ${ }_{66}$

Nardi's conclusion-based on the corrupted text of the 1841 editionthat Varchi was an Averroist, or perhaps followed Siger of Brabant (c. 1240-82), is erroneous. ${ }^{67}$ Varchi in fact supports the idea of the immortality of the soul, along with its only virtual divisibility according to its functions, and its real indivisibility as a single entity in the human being. In defending the concept of the immortality of the soul, Varchi states that if all internal senses deal with the body, the rational soul, on the contrary, "is not a body, nor a virtue in a body, nor does it require a corporeal instrument, if not by accident"; 68 it can therefore be considered immaterial, and hence immortal. Thus Varchi promises to explain

four very important and desired doubts for everyone. First: whether the soul is mortal or immortal. Second: whether the soul is multiplied in number in such a way that everyone has their own, or there is only one for all men. Third: whether the soul is a substantial form of man, and if it gives it the being and the operations, or does not, and is only an assistant, like the helmsman, who is the pilot of the boat. Fourth: whether in man there are one or more souls that are really distinct. ${ }^{69}$

Unfortunately, the second part of this lecture is missing, but a partial answer to these questions may be found in the Lezione sopra il primo canto

\footnotetext{
${ }^{65}$ Cf. O, 2: 524.

${ }^{66} \mathrm{O}, 2: 316$. In this case I follow Annalisa Andreoni's forthcoming critical edition of Varchi's Lectures, which reads "separable and immortal, not inseparable and mortal" instead of "inseparable and immortal, not separable and mortal."

${ }^{67}$ Cf. Nardi, Studi su Pietro Pomponazzi, 324. Nardi used Benedetto Varchi, Lezioni sul Dante e prose varie (Florence: Società Editrice delle Storie del Nardi e del Varchi, 1841).

${ }^{68} \mathrm{O}, 2: 350$.

${ }^{69}$ Ibid., 321.
} 


\section{Sgarbi $\downarrow$ Benedetto Varchi}

del Paradiso di Dante. Varchi points out that the rational soul is divided into two faculties: the possible intellect and the agent intellect. Aristotle also calls the possible intellect "material," and this, Varchi explains,

not because it is in such manner, being non-mixed and separate in itself from every matter, but he calls it with such a name because, as the prime matter that can receive all the sensible forms, and in relation to all of them is in potency, thus also this intellect can receive all intelligible things and in relation to all of them is in potency. ${ }^{70}$

The possible intellect is further divided into the speculative intellect and the practical intellect. The speculative, or contemplative, intellect has as its object universal things, and as its aim the contemplation of truth. The practical intellect, on the other hand, deals with particular things. Varchi emphasizes that these two intellects are the same as the possible intellect, only conceived in different ways and according to different operations and functions, and again he reiterates the substantial indivisibility of the intellect and the soul. Varchi also characterizes the speculative and practical intellects by means of Aristotle's five intellectual virtues, or habits, namely intelligence, science, wisdom, art, and prudence, and suggests, albeit implicitly, that these habits qualify each particular individual possible intellect. ${ }^{71}$

The agent intellect, on the other hand, is nobler than the possible intellect, and is called that because it can do everything, especially, following Averroes, transferring things from one order of knowledge to another, thus making sensible things intelligible. As Varchi writes, the agent intellect does not make things, "but it makes possible their understanding." 72 From Varchi's interpretation of the agent intellect we can deduce his conception of the soul. What the agent intellect is, according to Varchi, is a matter of debate:

Alexander [of Aphrodisias] says that it is the first cause, that is the divine intellect; Philoponus thinks that it is a faculty of the rational soul; others say that it is a middle substance between divine intellect and the human one, but is neither divine nor human. ${ }^{73}$

\footnotetext{
${ }^{70}$ Ibid., 351.

${ }^{71} \mathrm{~V}, 32 \mathrm{r}$.

${ }^{72} \mathrm{O}, 2: 351$.

73 Ibid.
} 
These are all positions with which he in fact disagrees, maintaining rather that:

Following Themistius, whose opinion appeared to be more congenial to the mind of Aristotle, according to the estimation of our teacher [Boccadiferro], we will say that the agent intellect is a faculty of the soul that is substantially distinct from the possible intellect, so that as the body and the soul result in one single thing, in the same way from the agent intellect as form and the possible intellect as matter one single thing is formed, which is the rational soul. $^{74}$

Varchi shares Themistius's view about the agent intellect—against "Alexander, the noblest Peripatetic," who held that the agent intellect was Godmaintaining a twofold position according to which the agent intellect is in itself a single separate substance, but as the form of the possible intellect, which is matter, it constitutes one single rational soul for each individual. Following Themistius, Varchi believes that the agent intellect is a part of the soul that is distinguished "substantially from the possible intellect, because in each being, where there is something in potency, there is also something in actuality, which transforms this potency into actuality, because otherwise this potency would be meaningless, which is not possible in nature." 75 The proper task of this agent intellect is therefore "to make all intelligible things in potency intelligible things in actuality," 76 to transform potency into actuality, just as the light makes visible all things that it is possible to see. Varchi's analogy of the agent intellect and light comes from Aristotle's De anima 3.5430 a 10-17, and receives particular emphasis in Themistius. Themistius writes that when light becomes present in the sight and in colors that are in potency, it turns them into actuality. Analogously, the agent intellect joins the possible intellect, acts on it, and acts on the intelligibles in potency, which are the species produced by the imagination and stored in the memory, turning them, like colors, into actuality. ${ }^{77}$ In

\footnotetext{
${ }^{74} \mathrm{Ibid}$.

${ }^{75} \mathrm{~V}, 31 \mathrm{r}$ : “. . . noi la crediamo, secondo Aristotile, parte dell'anima distinta sostanzialmente dall'intelletto possibile; perche in ciascuno ente, dove è alcuna cosa come potenza, si truova ancora alcuna cosa come atto, il quale riduce cotale potenza all'atto; perche altrame[n]te cotale potenza sarebbe in vano, il che la Natura non patisce."

${ }^{76}$ Ibid.: "l'ufficio di questo intelletto agente è di fare, che tutte le cose intelligibili in potenza, divengono intelligibili in atto."

77 Themistius, Themistii in libros Aristotelis de anima paraphrasis, 103-4.
} 


\section{Sgarbi $\downarrow$ Benedetto Varchi}

other words, the agent intellect, like a light, actualizes both the images in the soul and the possible intellect.

For both Themistius and Varchi, therefore, the agent intellect is the form of the possible intellect. But the possible intellect, as we have seen, is in a certain sense, being its form, identical to the imagination, which is specific to each individual. The agent intellect thus actualizes the possible intellect, which is specific to every individual human being. Being the form of the possible intellect, which is personal and individual, and being, in accordance to the containment thesis, the summit of the scale and the form of all previous forms, the agent intellect constitutes the essence of the human being. As essence, the agent intellect is separate from the individual human beings, but it is unique and the same for all humankind. The uniqueness of the agent intellect is necessary for both Themistius and Varchi, because otherwise, as we have seen, it would be impossible to explain the presence of common universal concepts in all human beings and their capacity to understand one another. Such uniqueness, however, does not prevent the agent intellect from being multiplied in the human beings like light, which is unique, but makes sight possible for all human beings. ${ }^{78}$ The analogy with light is important for Themistius and Varchi, because it allows them to explain how the agent intellect, although a separate being, can be located in the soul: "the agent intellect is in itself one, but it breaks up and enters different human subjects, just as natural light comes from a single source and breaks up in the different subjects receiving it." 79 Varchi's position, following Themistius, differs radically from that of Averroes, as the Florentine philosopher locates both the possible and agent intellects in the soul, while the Islamic philosopher conceives both intellects as eternal substances existing independently of the human soul. ${ }^{80}$

This idea of the multiplication and irradiation of the agent intellect is a characteristic element of the Platonic conception of the idea, which, although universal and unique, is nonetheless capable of becoming the essence of individual things. Following Themistius, ${ }^{81}$ but probably according to Zimara's Tabula (of which in this case Varchi's words seem to be a translation), ${ }^{82}$ the Florentine thinker points out that agent and possible

\footnotetext{
${ }^{78}$ Cf. ibid., 103.

${ }^{79}$ Herbert A. Davidson, Alfarabi, Avicenna, \& Averroes on Intellect. Their Cosmologies, Theories of the Active Intellect, \& Theories of Human Intellect (Oxford: Oxford University Press, 1992), 27.

${ }^{80}$ Cf. ibid., 319.

${ }^{81}$ Themistius, Themistii in libros Aristotelis de anima paraphrasis, 108.

${ }^{82}$ Zimara, Tabula dilucidationum in dictis Aristotelis et Averrois, 74r: "Intellectus agens et intellectus potentiae, partim duae naturae sunt, partim una. Nam et id quod ex duabus facultatibus forma, et materia conditur, unum esse intelligimus."
} 
intellects are in one sense two distinct natures, and in another sense the same nature. The agent intellect is the universal essence of humankind which, like the Platonic idea, and thanks to the possible intellect, which is its reverberation in matter, can be communicated to other individuals and be in them without losing its original and essential uniqueness.

To recapitulate, in Varchi there is only one agent intellect, which is the form of the lower forms of the soul, the possible intellect in particular. As the agent intellect, it is in itself unique, but as form, it is irradiated and divided among all individuals, like light making things visible. The agent intellect is the form of the possible intellect, and only in the conjunction between these two intellects, like in the conjunction of matter and form, is it possible to understand individuality. The compound of these two intellects constitutes the individual, as well as what he calls the rational soul, which he views as immortal. The problem now is to understand why for the Florentine thinker every single human being is, thanks to its rational soul, immortal. In this case also, Themistius's interpretation of Aristotle is the explanation. It is quite clear that the vegetative and sensitive souls perish with the body, and that the agent intellect, being incorporeal and in actuality, does not. The real question arises concerning the possible intellect, which is the imagination in actuality and the agent intellect in potency. According to Varchi, following Themistius, the immortal soul is not the compound itself of the possible and agent intellects, because the agent intellect is undoubtedly more separable and unmixed with the body than the possible intellect. When the two intellects become one by conjoining, however, that is, the rays of light proceeding from the agent intellect enter the human soul and join the possible intellect, the possible intellect shares the immortality that pertains by essence to the agent intellect. Now, since the agent intellect joins the possible intellect at least by the time the human soul understands intelligibles, the possible intellect, in this conjunction, must already attain immortality at that time..$^{83}$ In this way, Varchi is capable of saving the immortality of the rational soul for every individual human being.

By endorsing Themistius's position, Varchi is able to salvage both the personal immortality and indivisibility of the human soul in accordance with the doctrine of the Christian theologians, and the Aristotelian position, albeit in a form that is mixed with a particular kind of Platonism, and thereby to remain within the dictates of the papal bull.

${ }_{83}$ Cf. Davidson, Alfarabi, Avicenna, \& Averroes on Intellect, 40-41. 


\section{Sgarbi $\downarrow$ Benedetto Varchi}

\section{CONCLUSION}

The study of Varchi's psychological manuscript treatises reveals a different image of the Florentine philosopher from the one we are accustomed to from reconstructions based only on the published Lezioni, which seem to suggest little more than a faint trace of Averroism. A study of his hitherto unexamined manuscript works shows a far subtler thinker who cannot easily be categorized.

Varchi's position is generally based upon that of Themistius, which is an eclectic blend of Aristotelianism and Platonism. This allows him to make a rigorous distinction between theological and philosophical positions while avoiding lapses into the Averroistic heresy or errors condemned in the bull, Apostolici regiminis, especially in relation to ideas concerning the mortality and divisibility of the soul and the uniqueness of the possible intellect. Varchi cannot be considered an Averroist, whatever that may mean: he does not accept the uniqueness of the possible intellect, the divisibility of the human soul, the mortality of the individual intellect, or the identification of the agent intellect with God. Varchi is indeed an eclectic thinker who represents a fascinating chapter in sixteenth-century psychology and vernacular Aristotelianism, not only because his works and ideas remained and circulated primarily in manuscript form, but also because they responded to contextual demands and contemporary debates on the immortality of the soul, showing the high level of philosophical debate in the vernacular language. ${ }^{84}$

Università Ca' Foscari, Venice.

${ }^{84}$ This research has been possible thanks to the ERC Starting Grant 2013, n. 335949, "Aristotle in the Italian Vernacular: Rethinking Renaissance and Early-Modern Intellectual History (c. 1400-c. 1650).” 
Copyright of Journal of the History of Ideas is the property of University of Pennsylvania Press and its content may not be copied or emailed to multiple sites or posted to a listserv without the copyright holder's express written permission. However, users may print, download, or email articles for individual use. 